The Poetics of Translation 
I too am untranslatable.

Walt Whitman, "Song of Myself" 


\section{Willis Barnstone}
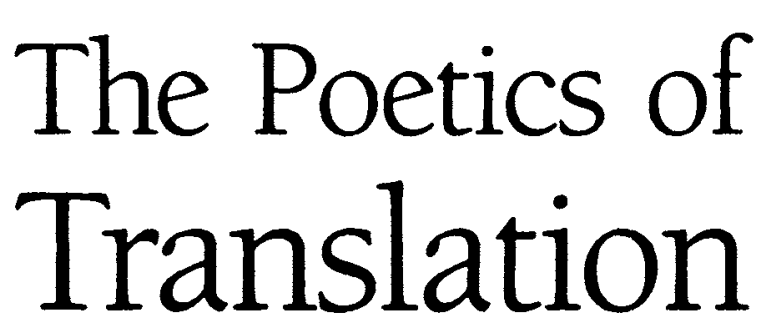

History, Theory, Practice

Yale University Press New Haven and London 
Published with assistance from the Kingsley Trust Association Publication Fund established by the Scroll and Key Society of Yale College.

Copyright 1993 by Yale University. All rights reserved. This book may not be reproduced, in whole or in part, including illustrations, in any form (beyond that copying permitted by Sections 107 and 108 of the U.S. Copyright Law and except by reviewers for the public press), without written permission from the publishers.

Printed in the United States of America

\section{Library of Congress Cataloging-in-Publication Data}

Barnstone, Willis, 1927-

The poetics of translation : history, theory, practice / Willis Barnstone.

p. $\mathrm{cm}$

Includes bibliographical references and index.

ISBN 0-300-05189-1 (cloth)

ISBN 978-0-300-06300-4

1. Translating and interpreting. 2. Bible-Versions-History.

1. Title.

P306.B287 1993

$418^{\prime} .02-\mathrm{dc} 20$

CIP

A catalogue record for this book is available from the British Library. The paper in this book meets the guidelines for permanence and durability of the Committee on Production Guidelines for Book Longevity of the Council on Library Resources. 
To David Michael Hertz for tuning the word and to Lowry Nelson, Jr., for rectifying mine 
As S. Augustine saith; A man had rather be with his dogge then with a stranger (whose tongue is strange unto him).

Miles Smith, preface to the King James Version

To a thousand cavils one answer is sufficient; the purpose of a writer is to be read, and the criticism which would destroy the power of pleasing must be blown aside.

Samuel Johnson, Life of Pope

[Greco-Roman writers] interest us, they matter to us, 1 repeat, as errors, not as masterpieces. We have scarcely anything to learn from them because of what they said, thought, and sang, but simply because they were, because they existed, because, poor men like ourselves, they swam desperately as we do in the perennial shipwreck of life.

José Ortega y Gasset, "Misery and Splendor of Translation"

Think of the Chinese translating the Sanskrit texts, or the Jews translating in Alexandria the Hebrew Testament and the Romans translating the Greeks. The history of the different civilizations is the history of their translations. Each civilization, each soul, is different, unique. Translation is our way to face this otherness of the universe and history. Octavio Paz in conversation with Edwin Honig

Iranslation saves you from your contemporaries.

Kenneth Rexroth, "The Poet as Translator" 